\title{
A görkorcsolyázás története I.
}

10.21486/recreation.2012.2.3.1

A görkorcsolyázás történetét megismerni vágyók az irodalmak felkutatása során rá kell, hogy döbbenjenek, hogy a magyar nyelven, a témában íródott könyvek, cikkek történelmi áttekintés fejezetei finoman szólva nem teljes körüek, ráadásul nagyon kevés a fellelhető anyag. Sokkal nagyobb a választék az interneten, a különböző nyelvü, honlapokon. Alaposabb tanulmányozás után kiderül az is, hogy sok az ismétlődés, az olyan irodalom, melyet hivatkozással, vagy hivatkozás nélkül valahonnan másoltak.

\section{Kulcsszavak: görkorcsolya, görkorcsolyázás, egysoros, párhuzamos, történet.}

\section{Keywords: skating, roller-skate, inline-skate, history.}
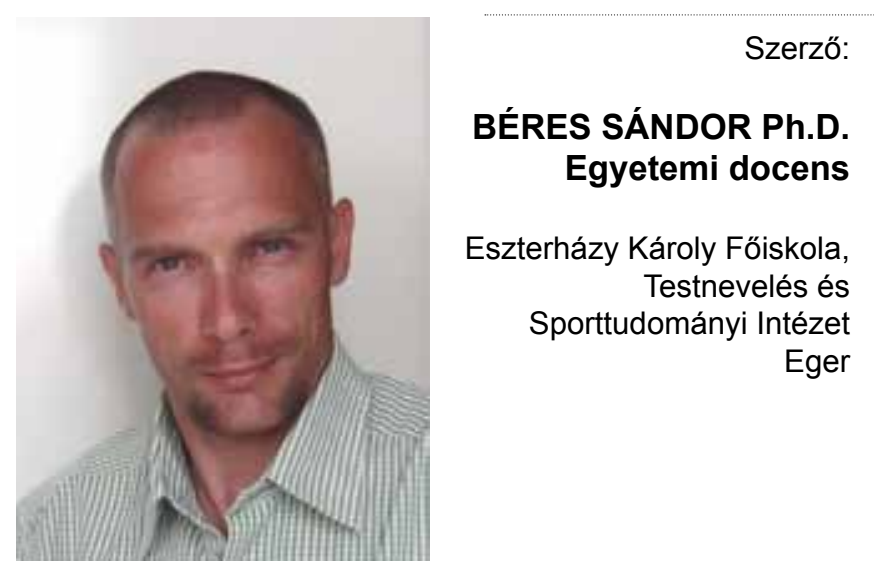

BEVEZETÉS
Az egyes források közel hasonló történeti vonalat vázolnak fel a kialakulást, fejlődést illetően, hol részletesebben, másutt címszavakban. Az igényesebb források több igen érdekes képet is közölnek a furcsábbnál furcsább megoldásokról, olykor részletekbe menő pontossággal, vagy apró, színes történetekkel vázolják az adott emlék hátterét.

A kutatás során ebben az esetben az a leghelyénvalóbb, ha az eredeti, vagy vélhetően a leghitelesebb lapot keressük fel, mely nem minden esetben hoz egyértelmű eredményt. A másik problematikája a témának az egyes görkorcsolya típusok kialakulása és azok elkülönülése. Az idők folyamán ugyanis érdekesebbnél érdekesebb megoldások láttak napvilágot az egy, két, három, négy, sőt tizennégy kerekü korcsolyákon át, az egysoros, párhuzamos, vagy úgynevezett kerékkorcsolyákig, vagy folytatható a sor a parkettára tervezett terem, vagy a szabadban használatos terep görkorcsolyákig. 
A görkorcsolyák felépítése, alkatrészei, pl. a kerekek úgyszintén elképesztő méret-, anyag- és egyéb tulajdonságainak változatossága is lehet kategóriateremtő lehetőség, a napjainkban annyira divatos „inline”, magyarul soros korcsolyák specializálódásáról, számtalan formájáról már nem is beszélve. Már önmagában is rendkívül érdekes. Az egyes feltalálók élete, munkássága. Szabadalmaikat olykor egymás ötleteinek továbbfejlesztésével adták be, de történeti szempontból - ha lehet így fogalmazni - az eredeti ötlet a legértékesebb a témát kutató számára. Bizonyos esetek azt mutatják, hogy előfordult olyan helyzet is, amikor vélhetően, szinte azonos időben, két „eredeti”, egymáshoz nagyon hasonlatos eszköz is születik.

\section{A GÖRKORCSOLYA KORAI MEGHATÁROZÁSA}

Az 1897-es kiadású Pallas Lexikon a következő meghatározást adja a „kerékkorcsolyázásra”:

„...kemény talajon, rendesen aszfalt- vagy cementpadozaton, karikás korcsolyákon üzött korcsolyázás. A kerékkorcsolya rendesen szijjakkal erősittetik a lábakra. Van 4, 3 és egy kerekü korcsolya; a négy kerék egyenlő nagyságú, és elhelyezkedésük olyan, mint a kocsikerekeké. A 3 kerekünél a kerekek a korcsolya talp közepén, egy sorjában vannak, a középső nagyobb, mint a kettő másik. Az egy kereküek kereke a lábak külső oldalára csatoltatik fel, a kerék $10-15 \mathrm{~cm}$ átmérőjü. Az elöbbi korcsolyák kerekei 2-3 cm magasak, keményfából vagy kaucsukból készülnek. ..."

E korai meghatározás nyilvánvalóan, nem a teljeségre törekvő precíz definíció bár az akkori állapotnak megfelelő pontos leírást próbálja adni. A görkorcsolyázás megfogalmazására az azóta eltelt idő során kialakult, szinte megfoghatatlan változatosság miatt nem vállalkoznék. Írom én ezt annak tudatában, mily szerteágazóan változatos e forradalmi eszköz formai, felhasználhatósági és történeti háttere.

\section{A GYÖKEREK ÉS AZ ELSŐ DOKUMENTÁLT GÖR- KORCSOLYÁK}

Carlesa Williams (2011) az amerikai Roller Skating múzeum történésze szerint a görkorcsolya és annak föleg "egysoros" változata valószínüleg a Skandináv országokból eredhet, ahol jégkorcsolyázás a legkönnyebb módja volt a rövid távolságok gyors megtételének. A korai 17. században azon Dánoknak, akik magukat „skeelers”-eknek hívták, szintén e tevékenység volt a legnépszerübb módszere a közlekedésnek, melyet télen a befagyott csatornák jegén oldottak meg. A görkorcsolya - hivatalosan fel nem jegyzett - őse valójában egy a párhuzamos korcsolya primitív formájára hasonlító korcsolya volt (roller skate), melynek aljára - egy falapra - spulnikat (orsó) erősítettek, melyek lehetővé tette a hasonló közlekedést melegebb időben is. ${ }^{1}$

A nagyközönség a kerekekkel felszerelt bakancsokról nagyjából a kerékpározás hajnalával egy időben hallhatott először.

Az első, dátumhoz köthető történet JOHN JOSEF MERLINRŐL szól, aki 1735. szeptember 17.-én a Belgiumban található Huys városkában született. A fiatal feltaláló később Párisban és Londonban dolgozott, ahol minőségi asztali- és karórákat, zeneszerszámokat és matematikai eszközöket tervezett és rakott össze.

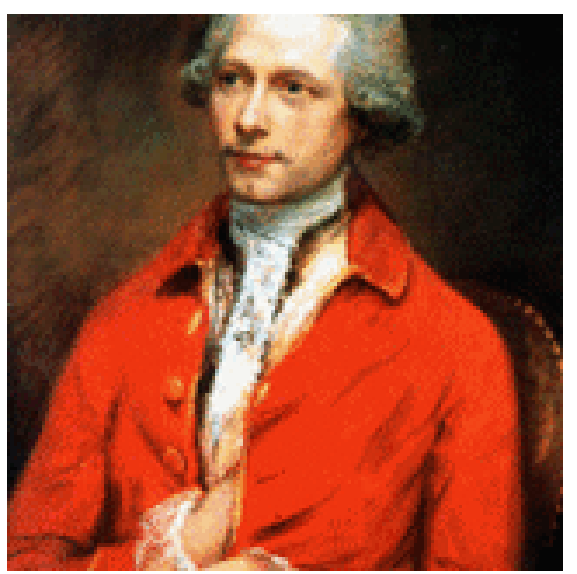

1. ábra John Joseph Merlin (National Museum of Roller Skating, USA)

Merlin zseniális műszerész és felfedező, de igazi foglalkozását tekintve zenész volt. Amikor huszonöt évesen 1760ban Londonba költözött, megnyitotta a "Merlin's Mechanical Museum"-ot. Ma is látogatható múzeuma a Hanover Square-n található és igen népszerü és szórakoztató hellyé vált, mint a mechanikai és zenei felfedezések bemutatóterme. A vendégek nyerőgépekkel játszhatnak, láthatnak örökké járó órát és mobil madár ketreceket, hallgathatnak zenedobozokat és pár shillingért még a kerekekkel ellátott széket is kipróbálhatják. ${ }^{2}$

Néhány Merlin egyéb találmányai közül:

»Manőverezhető, szedán kerekesszék, köszvényes embereknek - (manueverable sedan-type wheelchair for people with gout)

» Holland sütő (dutch oven)

» Örökmozgó, melynek mozgása az atmoszféra vál tozásoktól függ (perpetual motion machine that ran on atmospheric pressure changes)

» Mérleg gépek (weighing machines)

» Pianoforteként (korai zongora) használható csembaló (harpsicord with pianoforte action)

» Verkli, vagy sípláda (barrel organ)

» "Öszvér csembaló" (compuond harpsichord)

Merlin 1760-ban alkotta meg az első „rollerként” ismert korcsolyát, mely az első dokumentált görkorcsolya. A történelmi jelentőségü kori egymás mögött elhelyezett kicsi, fémkerékkel rendelkezett. Azért készítette, hogy a király kedvében járjon. Úgy vélik, hogy Merlin a korcsolyáit nyilvános mutatványai során viselte, ahol bemutatta találmányait, ezzel is menedzselve múzeumát. A megállás és a manőverezés viszont olyan problémát okozott, melyet nem tudott igazán megoldani, lévén nem rendelkezett semmi féle görkorcsolyás tapasztalattal, vagy gyakorlattal.

\footnotetext{
${ }^{1}$ http://inlineskating.about.com/od/inlineskatinghistory/a/inline_timeline.htm

${ }^{2}$ http://inlineskating.about.com/od/inlineskatinghistory/a/j_merlin.htm
} 
Egy mulatságos történet szerint Merlin az év februárjában, görkorcsolyájával jelent meg a „London Court”, labdateremben rendezett, elegáns jelmezbálon. A feltaláló, zenész tudományát is szerette volna bemutatni és hegedülés közben, mivel nem igazán tudott fékezni és kanyarodni, belerohant egy hatalmas álló tükörbe, súlyos sérüléseket szerezve. A tükör mellett összetört büszkesége is. Később még számos sérülést szerzett, de ez nem szegte kedvét. 3,4,5,6

Merlin bemutatta tehát görkorcsolyáját és demonstrálta görkorcsolyázást, de nem szabadalmaztatta azt (Franciaországban akkor még nem létezett sem szabadalmi hivatal, sem szabadalmi törvény). A következő évszázad során sok más korcsolya terv folytatta az egysoros kerék elrendezés kialakításának tökéletesítését. ${ }^{6}$

1789 a következő dátum az egysoros görkorcsolya fejlődésének történetében. Ebben az évben az ötlet tovább „gurult” Franciaországba, ahol LODEWIJIK MAXIMILIAN VAN LEDE megtervezte és elkészítette saját szavaival élve a „patin a terre"-t, ami szabad fordításban annyit tesz, hogy „terep-, vagy föld korcsolya". A korcsolya egy vas sínből és az arra szerelt fa kerekekből állt. Van Lede a párizsi Bruge Akadémia különcnek tartott szobrásza volt. ${ }^{3}$

Az 1800-as évek közepén több feltaláló mutatkozott be több különböző típusú görkorcsolyával. Mindenki a Merlin-féle problémával küzdött, merev szerkezetük miatt nagyon nehéz volt irányítani őket. A következő évtizedben az „egysoros korcsolyák” terjedtek el leginkább. A kerekek száma kettő és hat között mozgott.

\section{A GÖRKORCSOLYA SZABADALMAK}

A görkorcsolya szabadalmaztatásának időpontja azért nem határozható meg, mert az egyes feltalálók közel egy időben egymástól függetlenül jelentették be szabadalmaikat. A másik ok, ami miatt az „első szabadalmaztatást” felesleges lenne meghatározni az az, hogy a szabadalmi hivatalok létrejötte az egyes országokban, szintén erre a korra datálható, kisebb nagyobb eltérésekkel. Angliában 1623-ban, USA-ban 1790-ben, Franciaországban 1791-ben nyílt ilyen hivatal. A szabadalmi törvények megalkotása is más időpontokban volt. Franciaországban 1844-ben, Belgiumban 1854-ben, Olaszországban 1859-ben. ${ }^{7}$

Franciaországban PETITBLED, 1819-ben, Párizsban szabadalmaztatja elöször az egysoros görkorcsolyát. ${ }^{8} \mathrm{~A}$ szabadalom roller skate elnevezéssel kerül bejegyzésre, amely ma a görkorcsolya párhuzamos fajtát takarja, de a korcsolya ugyanakkor ,inline”, vagyis egysoros volt. M. PETITBLED találmánya fatalppal, bőrszíjjal és három kerékkel rendelkezett. (2. ábra) A kerekek fából, fémböl vagy elefántcsontból készültek. Úgy gondolta, hogy találmánya alkalmas a jégkorcsolyázó mozgás utánzására, de ezt a kerék konstrukció nem igazán engedte, mert azok csúsztak a kemény felszínen.

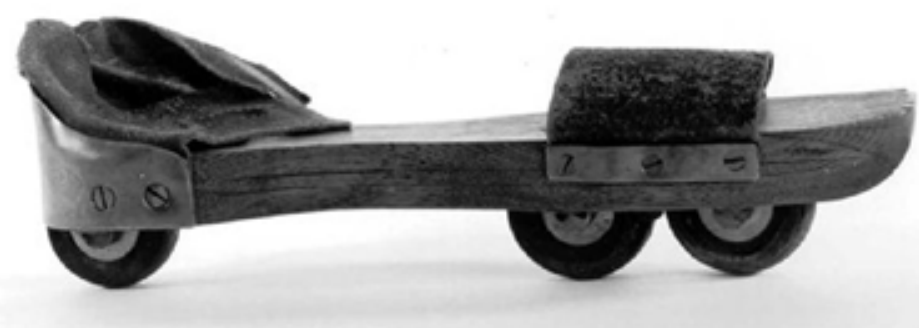

2. ábra A Petitbeld korcsolya. Fa talp, bőr szíjak.

Már egy évvel PETITBELD szabadalma előtt, 1818-ban berlini a balettben a jégkorcsolyát utánzó mozgásokat egysoros görkorcsolyák használatával oldották meg, mivel a színpadon lehetetlen volt jeget létrehozni. A balett, címe Der Maler oder die Wintervergn Ugungen azaz "A művész, avagy a téli örömök”. A jégkorcsolyázás az egyike volt a téli örömöknek, melyet görkorcsolyával utánozhattak. Senki sem tudja milyen korcsolyákat használtak tulajdonképpen.

1823-ban a brit ROBERT JOHN TYLER a londoni jégkorcsolyázó megalkotta a "Rolito ${ }^{9}$ vagy Volito ${ }^{10 ”}$ görkorcsolyát, amelynek talpához egy sorban, öt kereket erősített. A középső kerék nagyobb volt, mint a többi és a kerekek az utolsó felé egyre kisebbek voltak, mely alkalmassá tette a görkorcsolyát arra, hogy a testsúly előretolásával jobban manőverezhető legyen. Ugyanakkor a Rolito-val nem lehetett olyan íveket húzni, mint a mai egysoros korcsolyákkal, bár az is igaz, hogy a korcsolyán elhelyezett horogszerű fékekkel, már lehetett fékezni is. ${ }^{9,11}$

\footnotetext{
${ }^{3}$ http://inlineskating.about.com/od/inlineskatinghistory/a/inline_ timeline.htm

4 Jafcsák Péter: Görkorcsolyázás, A Semmelweis Egyetem Testnevelés és Sporttudományi Kara (TF), 2002 Plantin Print Bt., Budapest ${ }^{5}$ Lading, G., \& Frank, R. (2011). Görkorcsolyázás. Budapest: Cser Kiadó, 8.o.

${ }^{6}$ Részlet Merlin életét bemutató honlapról. John Joseph Merlin: Father of Inline Skating, Merlin was an Imaginative Inventor, By Carlesa Williams, About.com Guide, http://inlineskating.about.com/od/ inlineskatinghistory/a/j_merlin.htm

${ }^{7}$ Britannica's 1999 CD-ROM Encyclopædia, Multimedia Edition, Chicago,08.24.1998

${ }^{8} \mathrm{http}: / /$ skatehereford.co.uk/Historyofrollerskating.aspx

${ }^{9} \mathrm{http}: / /$ inlineskating.about.com/od/inlineskatinghistory/a/inline timeline_2.htm

${ }^{10} \mathrm{http}: / /$ www.loe.org/shows/segments.html?programID=03-P13 00016\&segmentID=3

${ }^{11} \mathrm{http}: / /$ www.loe.org/shows/segments.html?programlD=03-P1300016\&segmentID=3
} 

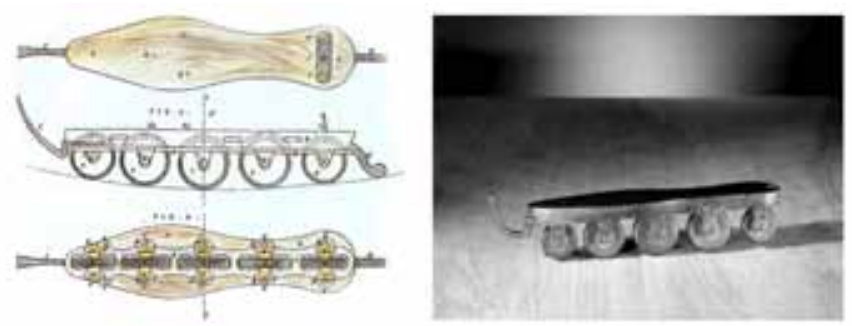

3. ábra A Volito korcsolya - Foto: National Museum of American History, Smithsonian Institution; Rajz forrása: (Bonnefon, 2005)

Ebben az évtizedben egy másik görkorcsolya szabadalom is bejegyzésre került, egészen pontosan 1828-ban Ausztriában, AUGUST LOHNER által, aki egy bécsi órakészítő mester volt. Egészen addig az összes görkorcsolya terv inline, tehát egysoros volt, de LOHNER terve egy triciklire hasonlított leginkább, mely tricikli két hátsó és egy első kerékkel rendelkezett. A korcsolyát felszerelte egy visszagurulás gátló zárópecekkel. ${ }^{12}$

Franciaországban JEAN GARCIN a „Cingar” fantázianevü görkorcsolyára kapott szabadalmat, mely nevet saját nevének összevonásával szerkesztett. Egyes források e szabadalom időpontját 1815-re ${ }^{13,14}$ mások 1828-ra ${ }^{15,16}$ teszik. A „Cingar” egysoros (inline) görkorcsolya volt három kerékkel. GARCIN korábban görkorcsolya pályát is nyitott, melyet végül be kellett zárnia a sok baleset miatt. ${ }^{17}$

Garcin 1813-ban írt egy könyvet, melynek címe La Vrai Patineur ou Principes sur l'Art dePatiner avec grace ... (Az igaz korcsolyázó ...). A könyv az első francia kézikönyv, mely a jégkorcsolyázás művészetéről szól. Gyönyörü, kézzel színezett, művészi metszetekkel illusztrálva mutatja be jégkorcsolyázók mozdulatait. Szintén jelentős abból a szempontból, hogy a korcsolyázás terminológiáját tekintve először közöl szótárformába foglalt, szaknyelvi kifejezéseket. GARCIN messze kora elött járt szakmáját tekintve. A könyv különös hangsúlyt fektet a jégkorcsolyázás esztétikumára, melyet közel 40 évig nem tanulmányoztak és publikáltak utána, míg végül elfogadottá vált és érdeklödésre tett számot a nagyközönség részéröl. Egy francia könyvkereskedés által leírt jellemzésében a könyv „...még mindig olyan ékszer, mely leírja és bemutatja a különböző, a jégkorcsolyázás akkori állapotának megfelelő figurát, kombinációt, azok

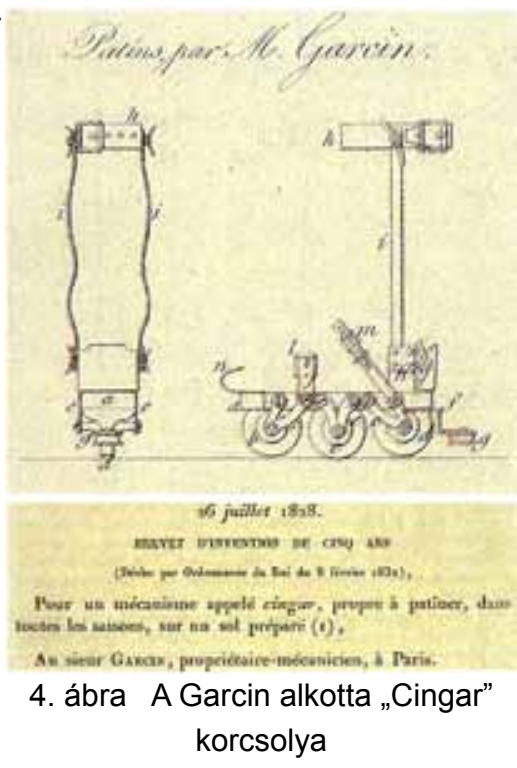

teljes és komplett variációit”. A legkorábbi különálló munka mely teljes egészében a jégkorcsolyázásról íródott, bármely nyelvet tekintve is. ${ }^{18}$

A XIX. század második felétöl a görkorcsolya egyre több helyen tünik fel. Íme, néhány jelentősebb dátum, melyet a W. CARLESA gyüjtött össze és publikált az amerikai Nemzeti Görkorcsolya Múzeum munkatársaként, annak honlapján. ${ }^{19}$

Monsieur és Madame DUMAS, profi táncosok 1840-ben különleges görkorcsolya (roller skating) elöadást tart a párizsi Port Saint Martin színházban. ${ }^{20}$

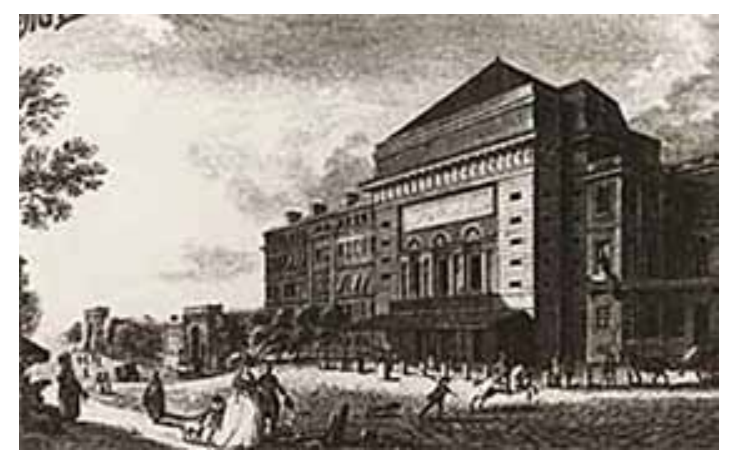

5. ábra Port Saint Martin színház, Párizs (1783)

Nem messze Berlintöl a Corse Halle Tavernben, megjelennek különleges, kerekeken guruló pincérlánykák, akik a nagyméretű sörcsarnokban csak így tudják megfelelően ellátni feladatukat a sörfelszolgálás terén... ${ }^{21}$

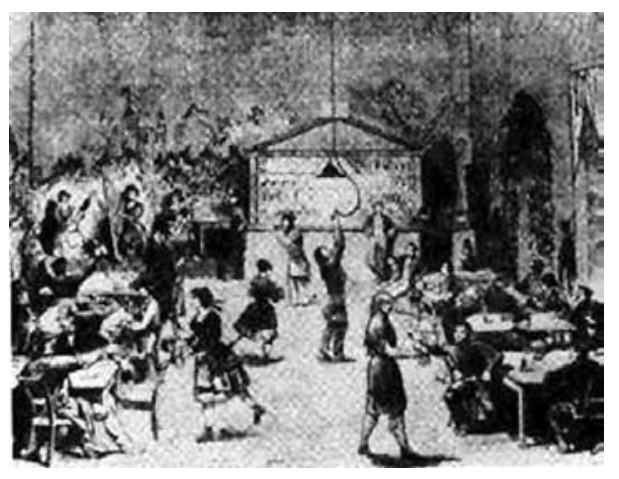

6. ábra Corse Halle Tavern, Berlin

Az egysoros kerékelrendezéssel szerelt korcsolya (a forrás szerint) első sikeres használatára 1849-ben került sor LOUIS LEGRANGE aki azért épített ilyen eszközt, hogy a jégkorcsolyázást szimulálhassa a „Próféta” című alkotásban a Francia Operában.22

\footnotetext{
${ }^{12} \mathrm{http}: / /$ skatehereford.co.uk/Historyofrollerskating.aspx

${ }^{13}$ (Jafcsák, 2002)

${ }^{14}$ (Lading \& Frank, 2011)

15 (Williams, The History of Inline Skate Development, 2011)

${ }^{16}$ (Herefordshire Roller skating Club, 2012)

17 (Bonnefon, 2005)

${ }^{18}$ (AbeBooks, 2012)

${ }^{19}$ (Williams, The History of Inline Skate Development, 2011)

20 (BhVP - fonds ART, et coll.part. DR., 2009)

${ }^{21}$ (Pinhero, 2012)

${ }^{22}$ (Williams, The History of Inline Skate Development, 2011)
} 

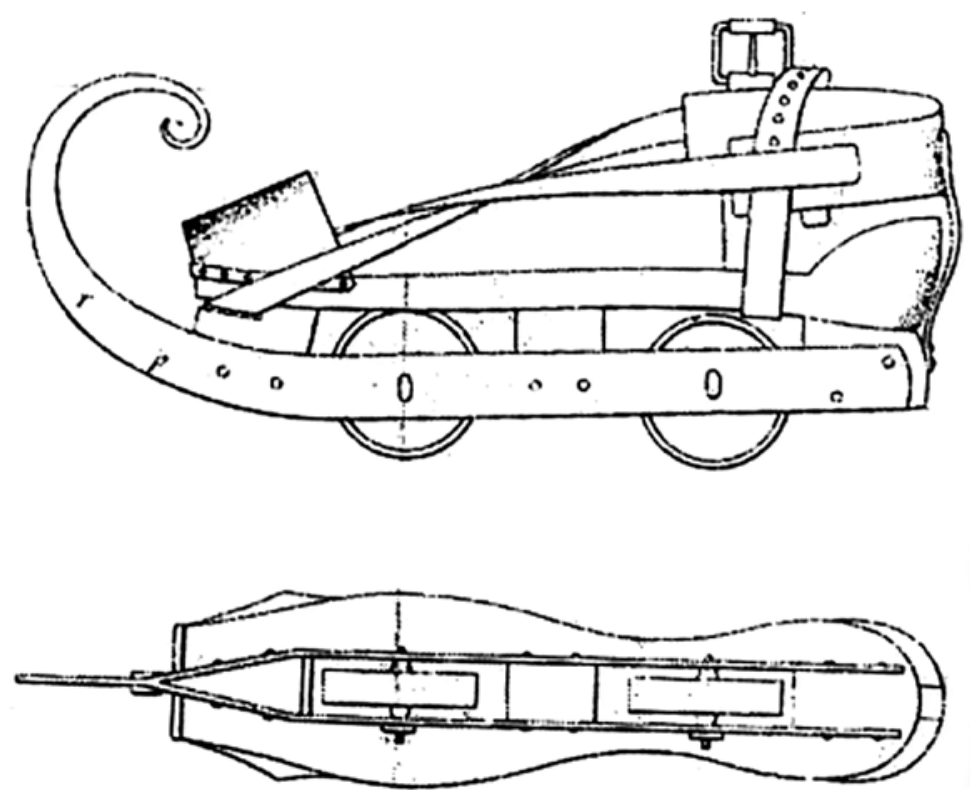

7. ábra A francia operában használt Legrange görkorcsolya ${ }^{23}$

1857-ban nyilvános görkorcsolyapálya nyílt a Strand of Londonon, a Floral Hall-ban. Ez a hely tulajdonképpen a Charles's Fowler neoklasszikus épületében van, mely London kora 19.-századi piac negyede volt. ${ }^{24}$

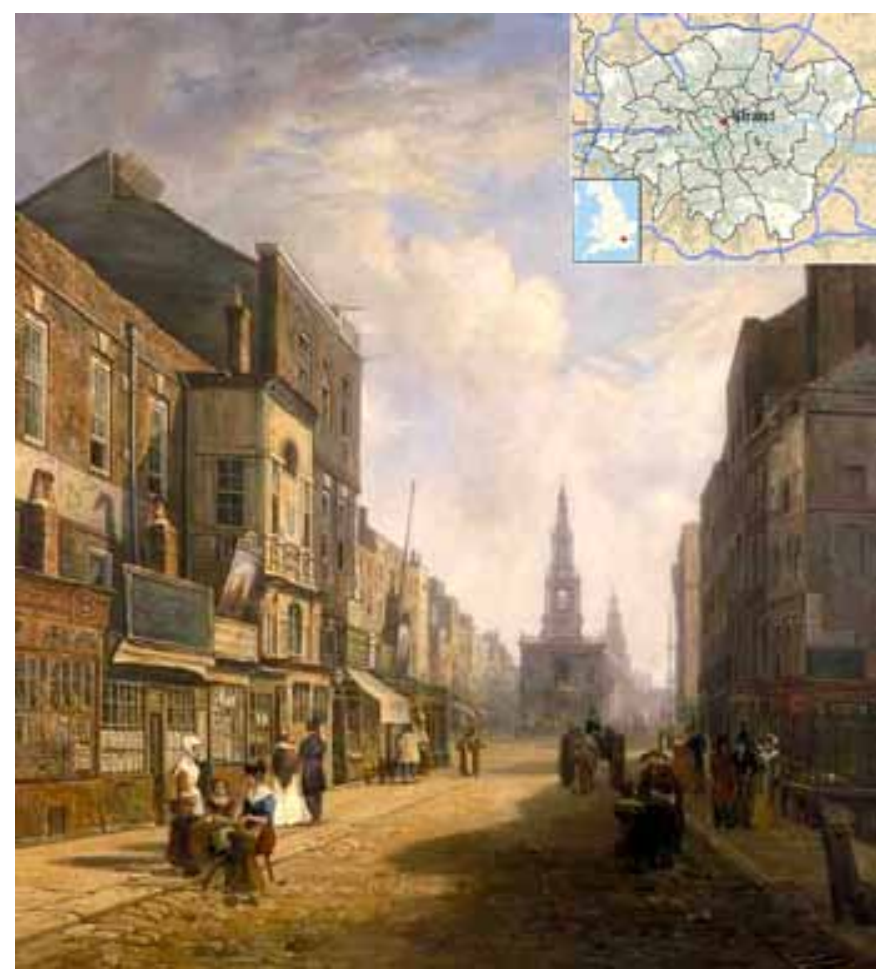

8. ábra Strand of London, 19. század eleje

A következő fejlesztés bizonyos WOODWARD úr nevéhez füződik, akiről a „Woodward skate” nevet is kapta. Az 1859es találmány lényege a vulkanizált gumival bevont kerekek alkalmazása, mely újítássokkal jobb kezelhetőséget biztosított a fa felületű padlón, mint a vas kerék. Ahogy a „Rolitónál” már láthattuk a középső kerekek ennél a korcsolyánál is nagyobbak voltak, mint a szélsők, mely a korcsolyát könnyebb fordulók kivitelezésére tették alkalmassá, azonban ez a megoldás a manőverezhetőség szempontjából továbbra sem volt igazán szerencsés.

Ilyen korcsolyát használt JACKSON HAINES a modern mükorcsolyázás megalapítója bemutatóin.

Az amerikai Fuller és Haines kiváló jég- és görkorcsolyázók egyben. Hamarosan rájöttek, hogy kamatoztathatják tudásukat, ha pénzért bemutatókon, show műsorokon csillogtatják meg tudásukat, mint például az akkor még különlegességnek számító forgást. Ekkortájt rendezték meg az első versenyeket is.

1868-ban Jackson Haines tovább szeretett volna fejlődni és elhatározta, hogy zenére fogja bemutatni táncát Bécsben. Elképzelése kisebb szervező munka után valóra is vált, mert a helyi szervezők biztosítottak számára zenei kíséretet és bemutatójának hatalmas sikere lett.

Az első nemzetközi jégtánc versenyen 1882-ben, a mükorcsolya és a tánc (figure \& dance) kategóriában mérhették össze tudásukat a versenyzők, melyet Haines hozott létre és a hosszú program megfelelője. Ekkorra e sport már magas müvészi szintet képviselt. Halála után Haines sírkövére a következőt vésték fel: „A korcsolyázók királya”. ${ }^{25}$

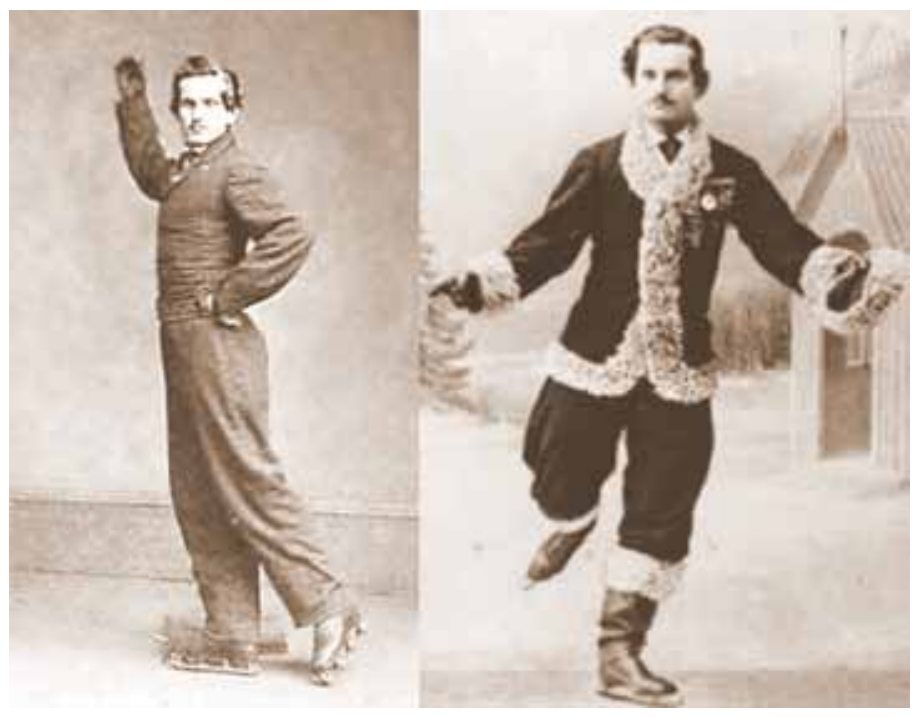

9. ábra Jackson Hines mükorcsolyázó ${ }^{26}$

A manőverezési problémákat az amerikai REUBEN SHALER (USA, Connecticut, Madison) feltaláló által 1860-ban létrehozott korcsolya dizájn oldja meg, aki már olyan elképzeléssel fejleszti görkorcsolyáját hogy az kifejezetten jól irányítható legyen. Shaler „Parlor Skate” néven jegyeztette be találmányát, mely az első ilyen jellegű szabadalom volt az Amerikai Egyesült Államokban.

\footnotetext{
${ }^{23}$ (Bonnefon, 2005)

24 (Wikipedia, 2012)

25 (Bonnefon, 2005)

${ }^{26}$ (EL PAIS S.A., 2009)
} 
A korcsolyának négy kereke volt, ezek szegecsekkel voltak egy $U$ alakú kerethez rögzítve, melyet mai szóhasználatban sínnek is nevezhetünk. A szabadalom javaslata szerint a kerekek felszínét gumi, vagy bör bevonattal érdemes ellátni, hogy bármely felületen megfelelően tapadjon. Ezek a megoldások, a forrás szerzője szerint (Williams, 2011) nem váltak be. Egy másik orosz szerző, azonban arról számol be (Mitskevichus А. , Очерки по истории изобретений, 2011), hogy a korcsolya kereskedelmi siker lett, sőt 1862-ben New Yorkban még egy útmutató is megjelenik a korcsolyázásról, melyet további három szórólap szerü anyag követ. A korcsolyák gyártása és a korcsolyázás népszerüsége ebben az időszakban jelentős mértékben nő, ugyanakkor a helyek száma, ahol e sportot gyakorolni lehetet még mindig meglehetősen kevés volt.
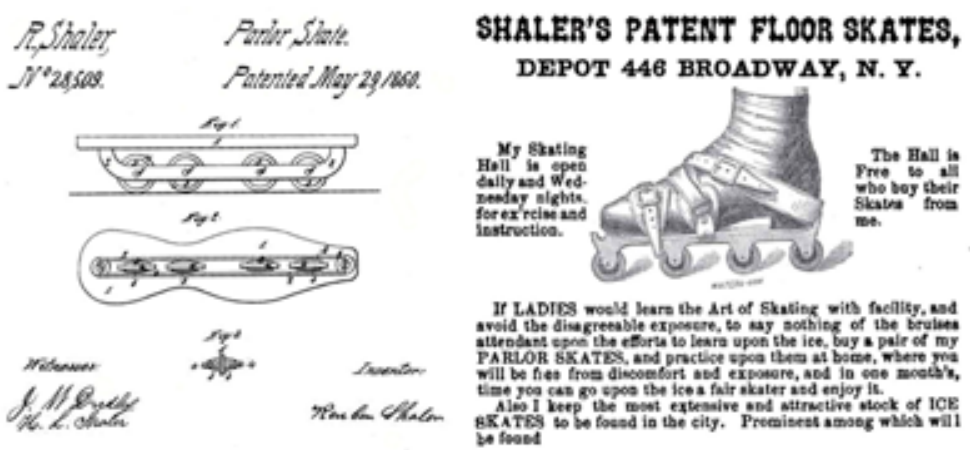

10. ábra Első ábra: Shaler 1860-as, amerikai inline görkorcsolya szabadalma ${ }^{27}$, Második ábra: Shaler Parlor korcsolyája. A felirat röviden ennyi: Görkorcsolya csarnokom minden nap és szerda éjszakánként nyitva áll mindazoknak, akik korcsolyáznának, vagy tanácsot kérnek. Azok, akik tőlem vásárolják korcsolyáikat a belépés ingyenes.... ${ }^{28}$

1863-ban JAMES LEONARD PLIMPTON feltalálta a kéttengelyü, kétsoros kerékelrendezésű (hívják még párhuzamosnak is; az angol forrás szerint quad; francia forrás szerint „rocking

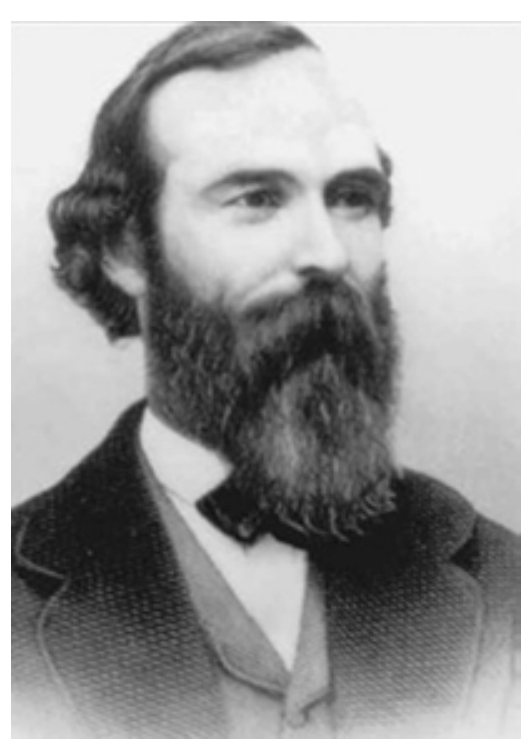

11. ábra James Plimpton ${ }^{29}$ skate") korcsolyát, mely jobb kontrolképességekkel bírt, továbbá sokkal könynyebb volt használni, mint az egysoros modelleket. ${ }^{29}$ Két kereket szerelt egy tengelyre annak két végére, ill. két tengelyt alkalmazott, így azok a síntől függetlenül is el tudtak fordulni, valamint gumicsillapítást használt, mely eredményeképp a korcsolyázó a kanyar vétel során abba az irányba dőlhetett, amerre kanyarodott. ${ }^{30}$ A korcsolya érdekessége volt továbbá, ${ }^{31}$ hogy a kerekeket ellátták egyfajta kenési rendszerrel, melyben a zsír külön tároló helyet kapott és természetesen a kerekeket kente. Ezek a korcsolyák viszonylag nehezek és általában koszosak voltak a zsírtól. Plimpton korcsolyáit a saját csarnokában bérbe adta a korcsolyázni vágyóknak.
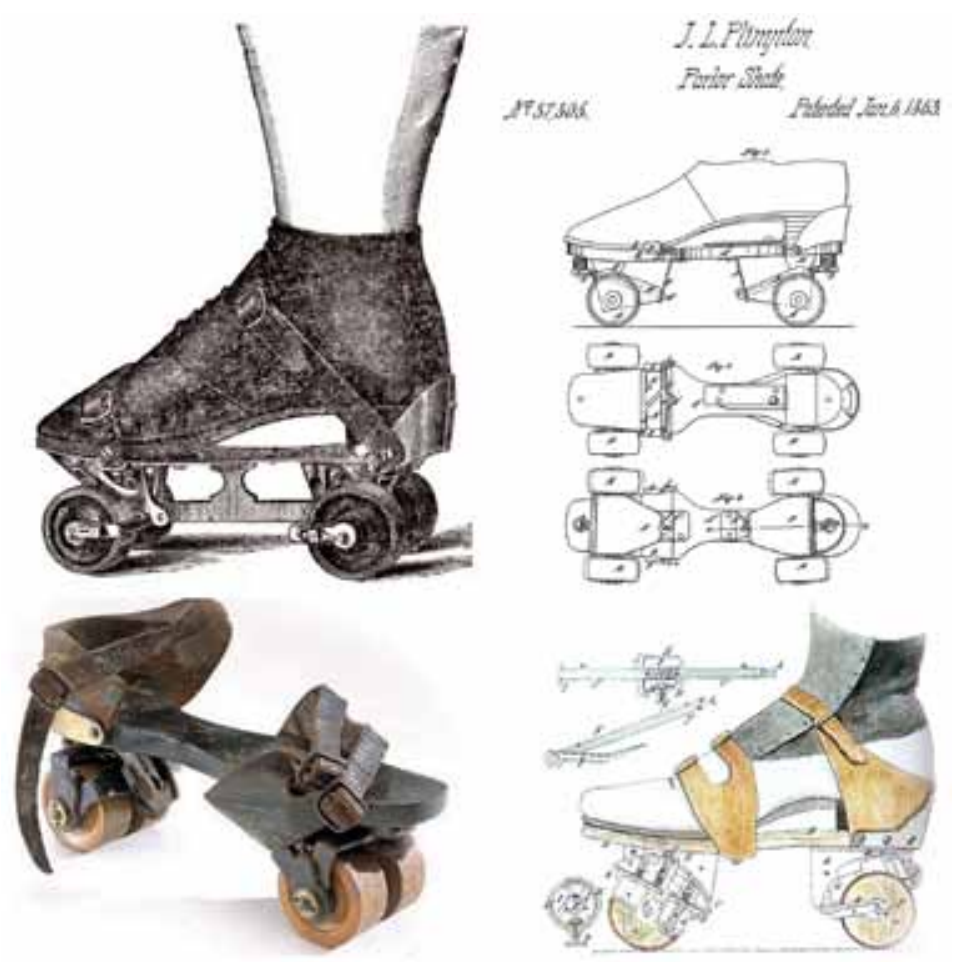

12. ábra A híres No 37305-ös szabadalmi számú, Plimpton párhuzamos (quad) görkorcsolya (1863) (22,33 $^{3}$

1866-ban megalapította az első new york-i görkorcsolya egyesület. Üzleti vállalkozása, a nyitott görkorcsolya pályák építése érdekében sokat utazott, északkeleten órákat adott, ezzel is elősegítve a görkorcsolyázás népszerüségének terjedését.

\section{A FÉKEK FELTALÁLÁSA}

Egy „hivatalosnak” mondható verzió szerint, 1876-ban Plimpton feltalálta párhuzamos görkorcsolyák még egy fontos alkatrészét, amely nélkül a modern görkorcsolyák szinte nem is léteznek, a féket (toe stop). Ez a tényt azonban sehol sem publikálja. Ennek az a következménye, hogy a kutatók bizonytalanok a fék feltalálójának személyét illetően is. Végül az Egyesült Államok szabadalmi hivatala 1864-ben, 3156482 szabadalmi számmal jegyzi a párhuzamos korcsolyák fékét (Mitskevichus A. , Очерки по истории изобретений, 2011).

${ }^{27}$ (Mitskevichus A. , 2011)

${ }^{28} \mathrm{https}$ ://lh6.googleusercontent.com/-e2tT0zeADC0/TYxfxxFWCII/ AAAAAAAAAXU/oXbzxeU5VPo/s400/018_05a_Shaler.jpg

${ }^{29}$ (The Roller Sakte, 2010)

30 (Williams, The History of Inline Skate Development, 2011)

31 (Bonnefon, 2005)

32 (Bonnefon, 2005)

33 (Mitskevichus A. , Очерки по истории изобретений, 2011) 

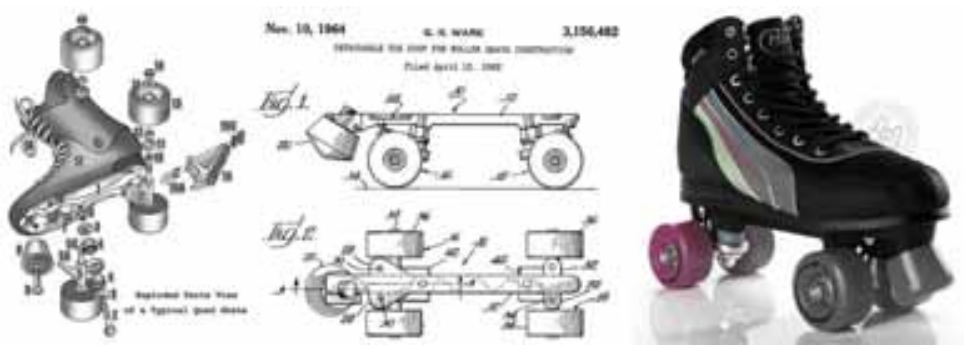

13. ábra A párhuzamos görkorcsolya fékének (toe stop) szabadalma 1964 G. K. Ware. (Mitskevichus, 2011)

A toe stop fékeket azonban nem csak fékezésre használják a korcsolyázók, hanem rugaszkodásra is. Főleg azokban a sportokban, ahol szükséges a gyors megindulás.

A görkorcsolyán alkalmazott fékek másik fajtájának feltalálója a szintén amerikai CYRUS WELLINGTON SALADEE, aki 1829-ben született Pennsylvaniában. Saladee Adam és Julia Mueller hetedik gyermekeként látta meg a napvilágot. Feltaláló volt, kinek neve mellé több mint 200 találmány jegyezhető. A legismertebb találmányai között említhető a könnyủ babakocsi és a Texas gőz eke (Texas Steam Plough). Sokat utazott, és amikor tehette magas cilindert viselt. Nagyon intelligens és excentrikus személy volt. Gyermeke nem volt, szinte minden idejét találmányainak szentelte. Ezek révén nagy vagyonra tett szert, végül 1894-ben Freeportban szegényen, morfium túladagolásban halt meg (Abel, 2012).

Saladee tehát a görkorcsolya fék 1876-os feltalálásával járult hozzá e sporteszköz fejlődéséhez, mely szabadalom után további megoldásokat is bejegyeztetett. Mindezek szintén nagyon jövedelmezőek voltak a számára.
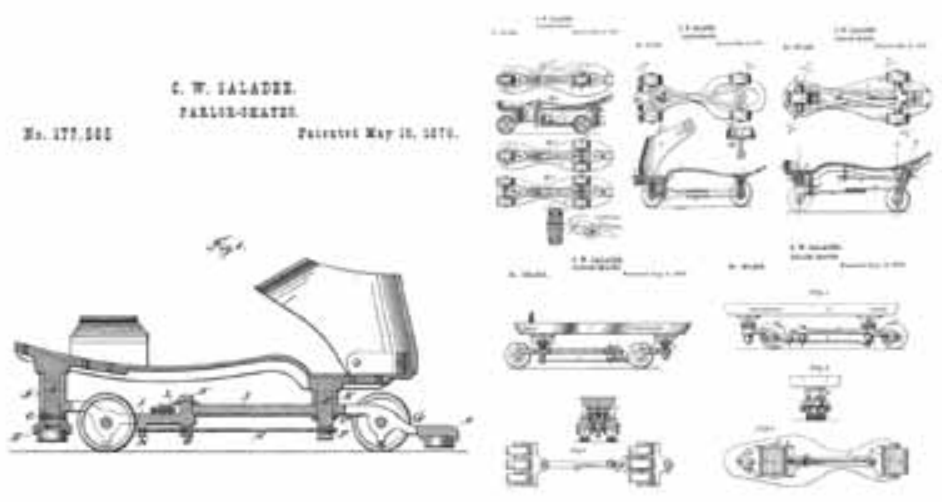

14. ábra A Saladee féle találmány, a fék - első (szabadalmi szám 177565) és további változatai (szabadalmi számok: 177565, 177566, 177.567,177568, 180646, 181868)

(Mitskevichus, 2011)

Az 1876-os év egyértelműen a görkorcsolya fékek feltalálásának éve volt, ugyanis egy másik igen érdekes megoldás született a görkorcsolyával való hatékonyabb fékezés eléréséhez. A № 182835 számú szabadalom egy bizonyos WILLIAM LOCKWOOD nevéhez füződik. A mechanizmus alapvetően eltér a Saladee rendszerétől. Lockwood elképzelése szerint a görkorcsolyázónak meg kell húzni egy kötelet, melyet korcsolyázás közben folyamatosan a kezében tart. A kötél egy görgő segítségével egy gumipadot szorít a kerékhez, mely lassítja azt. A megoldás talán ismerősnek tünhet, hiszen egy ehhez hasonló megoldás a prototípusa a kerékpár fékeknek, ill. a dörzskerekes dongómotorok is ezen az elven müködnek csak fordítva (Mitskevichus, 2011).

\section{W. LOCEWOOD. \\ PARLOR-SZATES.}

No. 182,835 .

Patented Oct. 3. 1876 .

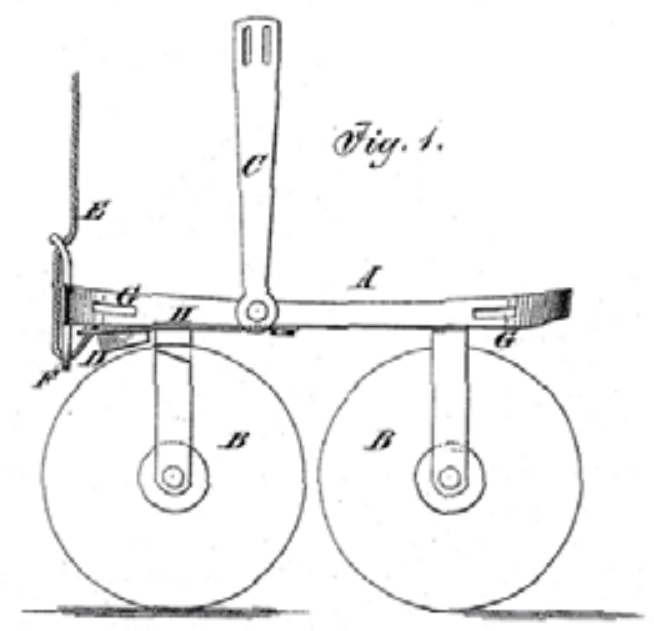

15. ábra Lockwood zsinóros megoldású dörzsféke 1876 (Mitskevichus, 2011)

\section{A GOLYÓSCSAPÁGYAK FELTALÁLÁSA}

A görkorcsolyák fejlesztésének következő és egyben utolsó lépése volt a golyóscsapágyak feltalálása és a kerekekben való alkalmazása. A görkorcsolyák kerekei az igénybevételtől, rázkódástól súrlódástól egy idő után elhasználódnak. $A$ leginkább igénybevett terület a kerekek és azok a felfüggesztéshez való kapcsolódásának pontja volt. Ezek mentek tönkre először. Az ezernyolcszázas években a felhasznált anyagok ráadásul nem voltak speciálisan az adott feladatra fejlesztve, ezért elengedhetetlenül szükséges volt valami olyan megoldás használata, mellyel a kerekek élettartamát növelni tudták.

A hivatalos verzió némileg ellentmondásos arról, hogy ki találta fel a golyóscsapágyat. Aki e gondolatot először papírra vetette és szabadalmaztatta JOSEPH GIDMAN volt 1852-ben. Olyan görkorcsolyát (roller skate) szabadalmaztatott, melybe elmélete szerint golyós csapággyal csökkentett a súrlódás. A szabadalom bejegyzése után közel 30 évet kellett várnia, hogy lássa azt a gyakorlatban is alkalmazni.

Érthetetlen módon a szakkönyvek mégsem Gidmant említik, mint feltaláló, valószínűleg azért, mert ő csak elméletben alkalmazta. Ennek dicsősége két birminghami (Anglia) feltalálót WILLIAM BROWN-t, és JOSEPH HENRY HUGHES-t illeti meg, akik 1867-ben szabadalmaztatták görgőscsapágyas kerekekkel szerelt görkorcsolyát. Ezzel a kijelentéssel 
nehéz vitatkozni, ugyanis nem fellelhető olyan forrás, mely egyértelmủen bizonyítja, hogy az említett tény nem felel meg a valóságnak. Ezen eszközök feltalálásának gyakorlati jelentösége természetesen jóval túlmutatott akkori felhasználásának keretein.

A következő, aki találmányával hozzátett a görkorcsolya fejlődéséhez LEVANT M. RICHARDSON, aki 1884-ben Chicagóban (USA) szabadalmi oltalmat kapott, az acélból készült golyóscsapággyal szerelt kerekü görkorcsolyákra. Ez az újítás bevezetésével a gurulási élmény szintén nagymértékben javult (Mitskevichus A. , 2011).

\section{M. RICHARDSON ROLLER SKATE.}

No. 308,990 . Patented Dec. 9, 1884.

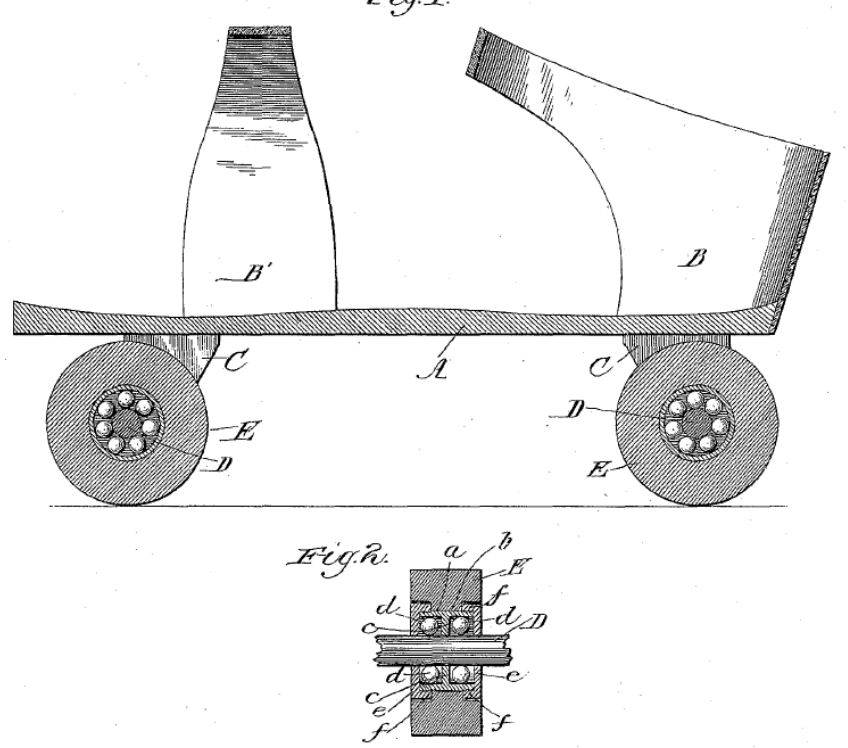

16. ábra A Richardson féle acél golyóscsapágyakkal szerelt görkorcsolya. Szabadalmi száma: 308990. 1884 Chicago (USA) (Mitskevichus A. , 2011)

Később 1898-ban Richardson megalapítja a Richardson csapágy és görkorcsolya gyárat (Richardson Ball Bearing and Skate Company). A gyár csapágyakat és görkorcsolyákat kezd gyártani és a korszellemnek megfelelően olyan görkorcsolyák fejlesztésébe kezd, melyek felvehetik a versenyt a lovaglással. Miután ugyanis lovagolni bármilyen felületen lehet, miért ne lehessen görkorcsolyázni is. Így kezdődik el a terep (crosscountry) görkorcsolyák első fejlesztése (Mitskevichus A. , 2011).

A fenti jelentős fejlesztések hozzájárultak ahhoz, hogy az ezerkilencszázas évekre ismét fellendült az érdeklődés a görkorcsolyázás iránt. A kereslet felmérte a kínálatot és újabb feltalálók, vállalkozók szálltak be az „iparba”. A görkorcsolyák gyártása nagyüzemi méreteket öltött.

MICAJAH C. HENLEY az amerikai Richmondban már több ezer korcsolyát gyártott hetente. Ezek a Henley korcsolyák voltak, ez első csavarral állítható, tengelyelfordulás kemény- séget szabályozó korcsolyák. Ez a megoldás a párhozamos korcsolyákon létező, úgynevezett Kingbolt mechanizmus őse (Mitskevichus A. , 2011).
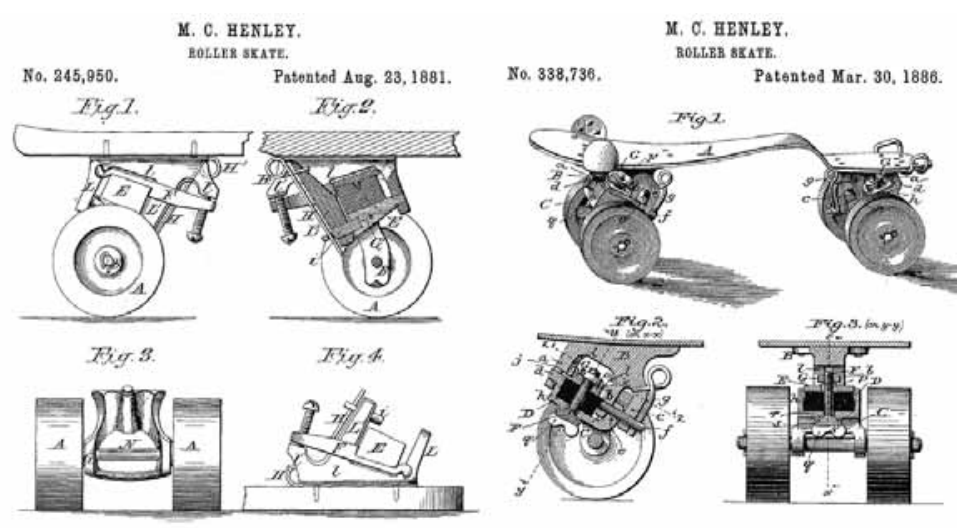

17. ábra Henley féle görkorcsolya szabadalom. Állitható tengelyelfordulási keménység. (Mitskevichus A. , 2011)

E kétsoros korik népszerüsége gyorsan nőtt Észak Amerikában és Európában. Hamar újra meghódították a korcsolya gyártó ipart is. Gyártásuk, népszerüségük okán túlsúlyba került. Néhány gyártó később folytatta az egy sorba rendezett kerekes korcsolyákat tervezését is, de ezt nem vették igazán komolyan. ${ }^{34}$

A párhuzamos vagy quad korcsolyák fejődése mellett természetesen a korcsolyázás történelméhez kapcsolhatóak azok a „vadhajtások” is melyek végül is zsákutcának bizonyultak, azonban ez nem von le jelentőségükböl.

\section{Folytatás és a teljes irodalomjegyzék a Görkorcsolyázás} története 2. címü cikkben. ${ }^{34} \mathrm{http} / / /$ inlineskating.about.com/od/inlineskatinghistory/a/inline_
timeline_2.htm 